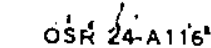

(REV 9-80)

$\rightarrow 13$

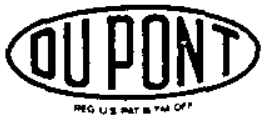

E. I. du Pont de Nemours \& Company

INCORPORATEO

ATOMIC ENERGY DIVISION

SaVANNaH River Laboratory

AIKEN, SOUTH Carolina 29808

(TWX: 8:0-771.2670. TEL 803.725-6211, WU: AUGUSTA, GA.)

DPST $-83-508 \mathrm{TL}$

June 17,1983

J. T. GRANAGHAN, MANAGER

SAVANNAH RIVER PLANT

ATTENTION: L. M. PAPOUCHADO, SUPERINTENDENT

SEPARATIONS TECHNOLOGY DEPARTMENT

STUDY OF PERSONNEL CONTAMINATIONS

IN 200 AREA FACILITIES

The attached memorandum by M. A. Wagner and D. H. Stoddard documents the frequency of personnel assimilations and contaminations in 200 Area facilities. The study (conducted for SRL's use in 200 Area Safety Analyses) is being transmitted to aid in your ongoing program to reduce and eliminate these incidents.

One surprising result deserves particular attention - A-Line in $F$ Area had the highest frequency of uptakes from 1970 through 1981 for all 200 Area facilities. This resulted from a large number of relatively low-level uranium assimilations that occurred in 1975. During this period, Construction employees were restoring the building after an explosion and fire. These assimilations were discovered through routine bioassays and were not attributable to any specific incident. With significant A-Line construction activity planned for the next several years via upgrade projects, the potential hazard from uranium assimilation should be emphasized. with all involved personnel.

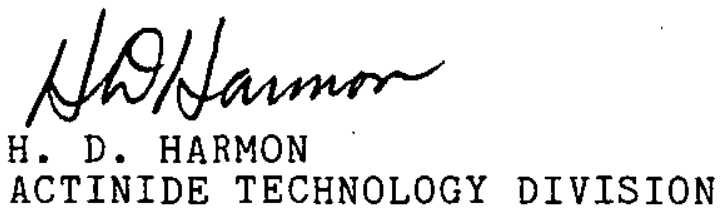

$\mathrm{HDH}: j \mathrm{mb}$

Att.

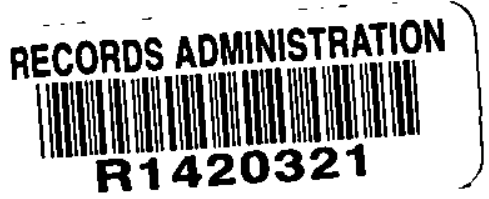


TECHNICAL DIVISION

SAVANNAH RIVER LABORATORY
DPST-83-508

ACP.NO. 1OZ336

\section{DISTRIBUTION :}

L. M. Papouchado, 703-A

W. C. Reinig, 703-A

C. H. Cofer, 704-F

R. M. Hal1, 735-A

K. Q. Gambil1, 735-A

S. D. Harris, 773-A

W. S. Durant, 773-26A (2)

R. M. Mobley, 773-A
M. B. Hughes, 773-A

W. V. Wright, 773-19A

W. C. Perkins, 773-26A

J. C. Huang, 773-26A

T. F. Schlaf, 773-26A

H. R. Haynes, 773-26A

R. Lee, 773-26A

P. M. Allen, 773-26A

SRL Records, 773-A (2)

May 18,1983

\section{MEMORANDUM}

To:

H. D. HARMON

FROM: M. A. WAGNER* AND D. H. STODDARD ACTINIDE TECHNOLOGY DIVISION

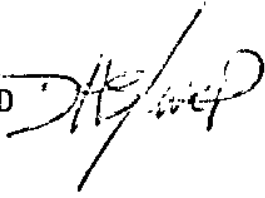

\section{A STATISTICAL ANALYSIS OF PERSONNEL CONTAMINATIONS IN 200 AREA FACILITIES}

\section{INTRODUCTION}

This study determined the frequency statistics of personnel contaminations in 200 Area facilities. These statistics are utilized in probability calculations for contamination risks, and are part of an effort to provide reliable information for use in safety studies. Data for this analysis were obtained from the 200 Area and the Tritium Area Fault Tree Data Banks and were analyzed with the aid of the STATPAC computer code.1,2

\section{SUMMARY}

Analyses were performed on confirmed uptakes and on nasa1, skin, and clothing contamination incidents in 200 Area facilities to obtain frequency statistics. The mean frequencies are as follows:

* Co-op student, Tennessee Tech. 
MEAN FREQUENCY OF PERSONNEL CONTAMINATIONS

(Events per Year)

\begin{tabular}{|c|c|c|c|c|c|c|c|}
\hline \multirow[b]{2}{*}{ Facility } & \multicolumn{4}{|c|}{ Uptakes } & \multirow[b]{2}{*}{$\begin{array}{l}\text { Nasal } \\
\text { Contam. }\end{array}$} & \multirow[b]{2}{*}{$\begin{array}{l}\text { Skin } \\
\text { Contam. }\end{array}$} & \multirow[b]{2}{*}{$\begin{array}{l}\text { Clothing } \\
\text { Contam. }\end{array}$} \\
\hline & $\begin{array}{l}\text { Inhala- } \\
\text { tion }\end{array}$ & $\begin{array}{l}\text { Injec- } \\
\text { tion }\end{array}$ & $\begin{array}{l}\text { Absorp- } \\
\text { tion }\end{array}$ & $\begin{array}{l}\text { Inges- } \\
\text { tion }\end{array}$ & & & \\
\hline F Canyon & 0.8 & 0.0 & 0.0 & 0.0 & 1.5 & 8.3 & 15.9 \\
\hline JB-Line & 3.7 & 0.1 & 0.0 & 0.0 & 8.7 & 24.3 & 36.5 \\
\hline $\begin{array}{l}\text { Laboratory } \\
772-\mathrm{F}\end{array}$ & 3.2 & 0.1 & 0.0 & 0.0 & 2.4 & 3.4 & 3.1 \\
\hline $235-F$ & 0.7 & 0.0 & 0.0 & 0.0 & 2.9 & 8.1 & 30.4 \\
\hline A-Line & 14.0 & 0.0 & 0.0 & 0.0 & 0.0 & 0.2 & 0.0 \\
\hline Burial Ground & 0.2 & 0.0 & 0.0 & 0.0 & 0.0 & 0.7 & 0.5 \\
\hline F Area Waste & 0.1 & 0.0 & 0.0 & 0.0 & 0.8 & 1.7 & 1.8 \\
\hline MPPF & 0.4 & 0.0 & 0.0 & 0.0 & 0.3 & 0.3 & 0.0 \\
\hline $\begin{array}{l}\text { F Area Outside } \\
\text { Facilities }\end{array}$ & 0.0 & 0.0 & 0.0 & 0.0 & 0.2 & 0.3 & 0.3 \\
\hline H Canyon & 3.1 & 0.1 & 0.0 & 0.0 & 2.4 & 15.2 & 19.2 \\
\hline $\mathrm{HB}-\mathrm{L}$ ine & 6.4 & 0.2 & 0.1 & 0.0 & 4.9 & 11.1 & 36.5 \\
\hline H Area Waste & 0.4 & 0.0 & 0.0 & 0.0 & 0.2 & 3.5 & 7.6 \\
\hline RBOF & 0.0 & 0.0 & 0.0 & 0.0 & 0.5 & 0.2 & 0.8 \\
\hline $\begin{array}{l}\text { H Area Outside } \\
\text { Facilities }\end{array}$ & 0.0 & 0.0 & 0.1 & 0.0 & 0.3 & 0.3 & 1.7 \\
\hline $\begin{array}{l}\text { Tritium } \\
232-\mathrm{H}\end{array}$ & 1.1 & 0.1 & 0.8 & 0.0 & - & - & - \\
\hline $\begin{array}{l}\text { Tritium } \\
234-\mathrm{H}, 236-\mathrm{H}\end{array}$ & 2.4 & 0.0 & 1.9 & 0.0 & - & - & - \\
\hline $\begin{array}{l}\text { Tritium } \\
237-\mathrm{H}, 238-\mathrm{H}\end{array}$ & 0.1 & 0.0 & 0.0 & 0.0 & - & - & - \\
\hline
\end{tabular}


DPST $-83-508$

\section{DISCUSSION}

This analysis was performed to determine the frequency statistics for personnel contaminations in the 200 Area facilities. The frequencies for confirmed uptakes and for nasal, skin, and clothing contaminations were analyzed, where enough data were available to give meaningful results. This statistical study concerns incidents from 1970 through 1981 for 200 Area uptakes (excluding tritium); 1976 through 1981 for $200^{\circ}$ Area nasal, skin, and clothing contaminations; and 1970 through 1982 for all tritium contamination incidents.

Data were obtained from the 200 Area and Tritium Area Fault Tree Data Banks, which are collections of incidents in those areas dating back to plant startup. The initial effort in this study was to update the data banks with assimilation information obtained from Health Protection Exposure Records for the years 1970 through 1981. Nearly 300 entries containing bioassay results were added to the 200 Area Fault Tree Data Bank, while 59 were added to the Tritium Data Bank. After integrating with existing material, the HP Exposure Records were found to have contributed 150 new incidents to the 200 Area bank and 26 new incidents to the tritium bank, primarily for 1970-1975 for which Health Protection log book data were not available.

The STATPAC computer code was utilized in performing the computations. After sorting specified incidents for each facility, STATPAC was used to calculate the arithmetic mean and median times between occurrences. The program also fitted the data to five different distributions: the normal, log-normal, exponential, Weibull, and log-uniform. A mean, median, and chi-square statistic were calculated for each distribution. STATPAC also plotted the probability density functions for each distribution and presented a trend plot of each contamination type for each facility.

Table 1 presents the results of the STATPAC analysis. It was determined that at least twelve incidents were required for STATPAC to work effectively. The best fit distribution was determined by comparison with the statistical mean and median value to the arithmetic mean and median.

With few exceptions, all uptakes in the 200 Area facilities were by inhalation. Within the indicated time spans, there was one uptake by injection in both $\mathrm{JB}-\mathrm{Line}$ and $772-\mathrm{F}$, two uptakes by injection and one uptake by absorption in HB-line, and one uptake by injection in $\mathrm{H}$ Canyon. In $\mathrm{H}$ Area, the only uptake for the outside facilities was by absorption. These numbers are included in the values in Table 1. In the Building 232-H tritium facility, there was one uptake by injection in addition to the other uptakes. 
The facility that had the highest frequency of both nasal and skin contaminations (based on data from 1976 through 1981) was $\mathrm{JB}-\mathrm{Line}$, while the highest frequency of clothing contaminations during the same period was in Building 235-F. The highest frequency of uptakes (based on data from 1970 through 1981) was in A-line. Most of these were relatively small uranium assimilations not attributable to any incident. Forty-seven percent of the uptakes in A-Line occurred during a two-month period in the spring of 1975, when construction employees were restoring the building after an explosion and fire. As Table 1 also shows, A-line had the lowest frequency of nasal, skin, and clothing contaminations for any non-tritium facility. Since the assimilations were discovered through routine bioassays, it would have been too late to have detected any nasal contaminations, if they had indeed existed.

Figure 1 is a typical probability density function. The height of each small block indicates the frequency of incidents during the time interval represented on the $X$ axis. The distribution curve is the best fit to the observed data.

Figures 2 through 8 are trend plots which show the number of incidents for the represented years and indicate an increasing or decreasing trend for that facility. Trend plots for other facility and contamination situations are not representative due to a lack of data points. 


\section{REFERENCES}

1. W. S. Durant, W. D. Galloway, P. M. Allen, and R. Lee. 200 Area Fault Tree Data Bank - 1982 Status Report. DPST-83-235 (January 24, 1983).

2. D. H. Stoddard, H. R. Haynes, and W. D. Galloway. Tritium Area Fault Tree Data Bank - 1982 Status Report. DPST-82-875 (September 28, 1982). 
TABLE 1

STATPAC Analysis Results

\begin{tabular}{|c|c|c|c|c|c|c|}
\hline Facility & $\begin{array}{l}\text { Contami- } \\
\text { nation } \\
\text { Type }\end{array}$ & $\begin{array}{l}\text { No. of } \\
\text { Incidents } \\
\end{array}$ & $\begin{array}{l}\text { Best Fit } \\
\text { Distribution }\end{array}$ & $\begin{array}{l}\text { Mean Time } \\
\text { Between } \\
\text { Occurrences } \\
\text { (Days) } \\
\end{array}$ & $\begin{array}{l}\text { Median Time } \\
\text { Between } \\
\text { Occurrences } \\
\text { (Days) } \\
\end{array}$ & $\begin{array}{l}\text { Years } \\
\text { Included } \\
\end{array}$ \\
\hline \multirow[t]{4}{*}{ F Canyon } & Uptake & 9 & - & 486 & - & $1970-1981$ \\
\hline & Nasa 1 & 9 & - & 243 & - & $1976-1981$ \\
\hline & Skin & 42 & Weibu 11 & 44 & 20 & $1976-1981$ \\
\hline & Clothing & 76 & Weibull & 23 & 5 & $1976-1981$ \\
\hline \multirow[t]{4}{*}{ JB-Line } & Uptake & 36 & Weibul1 & 98 & 47 & $1970-1981$ \\
\hline & Nasal & 41 & Weibull & 42 & 17 & $1976-1981$ \\
\hline & Skin & 114 & Weibu 11 & 15 & 7 & $1976-1981$ \\
\hline & Clothing & 230 & Log-Norma I & 10 & 4 & $1976-1981$ \\
\hline Laboratory & Uptake & 37 & Weibu11 & 115 & 41 & $1970-1981$ \\
\hline \multirow[t]{3}{*}{$772-F$} & Nasal & 12 & Weibu 11 & 155 & 107 & $1976-1981$ \\
\hline & Skin & 18 & Weibull & 106 & 74 & $1976-1981$ \\
\hline & clothing & 20 & Weibu 11 & 116 & 40 & $1976-1981$ \\
\hline \multirow[t]{4}{*}{$235-F$} & Uptake & 8 & - & 547 & - & $1970-1981$ \\
\hline & Nasal & 12 & Weibull & 125 & 20 & $1976-1981$ \\
\hline & Skin & 42 & Weibul1 & 45 & 8 & $1976-1981$ \\
\hline & Clothing & 259 & Log-Norma 1 & 12 & 4 & $1976-1981$ \\
\hline \multirow[t]{4}{*}{ A-Line } & Uptake & 74 & Weibull & .26 & 6 & $1970-1981$ \\
\hline & Nasal & 0 & - & - & - & $1976-1981$ \\
\hline & Skin & 1 & - & 2190 & - & $1976-1981$ \\
\hline & Clothing & 0 & - & - & - & $1976-1981$ \\
\hline Burial & Uptake & 2 & - & 2190 & - & $1970-1981$ \\
\hline \multirow[t]{3}{*}{ Ground } & Nasal & 0 & - & - & - & $1976-1981$ \\
\hline & Skin & 4 & - & 547 & - & $1976-1981$ \\
\hline & Clothing & 3 & - & 730 & - & $1976-1981$ \\
\hline F Area & Uptake & 1 & - & 4380 & - & $1970-1981$ \\
\hline \multirow[t]{3}{*}{ Waste } & Nasal & 5 & - & 438 & - & $1976-1981$ \\
\hline & Skin & 10 & - & 219 & - & $1976-1981$ \\
\hline & Clothing & 11 & - & 199 & - & $1976-1981$ \\
\hline \multirow[t]{4}{*}{ MPPF } & Uptake & 5 & - & 876 & - & $1970-1981$ \\
\hline & Nasa 1 & 2 & - & 1095 & - & $1976-1981$ \\
\hline & Skin & 2 & - & 1095 & - & $1976-1981$ \\
\hline & Clothing & 0 & - & - & - & $1976-1981$ \\
\hline
\end{tabular}

* Arithmetic mean values are shown where insufficient data were available to permit a STATPAC analysis. 
TABLE 1 (Contd)

\begin{tabular}{|c|c|c|c|c|c|c|}
\hline Facility & $\begin{array}{l}\text { Contami- } \\
\text { nation } \\
\text { Type } \\
\end{array}$ & $\begin{array}{l}\text { No. of } \\
\text { Incidents }\end{array}$ & $\begin{array}{l}\text { Best Fit } \\
\text { Distribution }\end{array}$ & $\begin{array}{l}\text { Mean Time } \\
\text { Between } \\
\text { Occurrences } \\
\text { (Days) } \\
\end{array}$ & $\begin{array}{l}\text { Median Time } \\
\text { Between } \\
\text { Occurrences } \\
\text { (Days) } \\
\end{array}$ & $\begin{array}{l}\text { Years } \\
\text { Included }\end{array}$ \\
\hline $\begin{array}{l}\text { F Area } \\
\text { Outside } \\
\text { Facilities }\end{array}$ & $\begin{array}{l}\text { Uptake } \\
\text { Nasal } \\
\text { Skin } \\
\text { Clothing }\end{array}$ & $\begin{array}{l}0 \\
1 \\
2 \\
2\end{array}$ & $\begin{array}{l}- \\
- \\
-\end{array}$ & $\begin{array}{l}- \\
2190 \\
1095 \\
1095\end{array}$ & $\begin{array}{l}- \\
- \\
-\end{array}$ & $\begin{array}{l}1970-1981 \\
1976-1981 \\
1976-1981 \\
1976-1981\end{array}$ \\
\hline H Canyon & $\begin{array}{l}\text { Uptake } \\
\text { Nasal } \\
\text { Skin } \\
\text { Clothing }\end{array}$ & $\begin{array}{l}38 \\
10 \\
81 \\
102\end{array}$ & $\begin{array}{l}\text { Weibull } \\
\text { Weibull } \\
\text { Weibull }\end{array}$ & $\begin{array}{l}116 \\
151 \\
24 \\
19\end{array}$ & $\begin{array}{l}14 \\
35 \\
8 \\
6\end{array}$ & $\begin{array}{l}1970-1981 \\
1976-1981 \\
1976-1981 \\
1976-1981\end{array}$ \\
\hline HB-Line & $\begin{array}{l}\text { Uptake } \\
\text { Nasal } \\
\text { Skin } \\
\text { Clothing }\end{array}$ & $\begin{array}{l}65 \\
22 \\
55 \\
190\end{array}$ & $\begin{array}{l}\text { Weibull } \\
\text { Exponential } \\
\text { Exponential } \\
\text { Weibull }\end{array}$ & $\begin{array}{l}57 \\
74 \\
33 \\
10\end{array}$ & $\begin{array}{l}21 \\
51 \\
23 \\
5\end{array}$ & $\begin{array}{l}1970-1981 \\
1976-1981 \\
1976-1981 \\
1976-1981\end{array}$ \\
\hline $\begin{array}{l}\text { H Area } \\
\text { Waste }\end{array}$ & $\begin{array}{l}\text { Uptake } \\
\text { Nasal } \\
\text { Skin } \\
\text { Clothing }\end{array}$ & $\begin{array}{l}5 \\
1 \\
24 \\
45\end{array}$ & $\begin{array}{l}- \\
- \\
\text { Weibu11 } \\
\text { Weibu11 }\end{array}$ & $\begin{array}{l}876 \\
2190 \\
105 \\
48\end{array}$ & $\begin{array}{l}- \\
- \\
14 \\
10\end{array}$ & $\begin{array}{l}1970-1981 \\
1976-1981 \\
1976-1981 \\
1976-1981\end{array}$ \\
\hline RBOF & $\begin{array}{l}\text { Uptake } \\
\text { Nasa1 } \\
\text { Skin } \\
\text { Clothing }\end{array}$ & $\begin{array}{l}0 \\
3 \\
1 \\
5\end{array}$ & $\begin{array}{l}- \\
\overline{-} \\
-\end{array}$ & $\begin{array}{l}- \\
730 \\
2190 \\
438\end{array}$ & $\begin{array}{l}- \\
- \\
-\end{array}$ & $\begin{array}{l}1970-1981 \\
1976-1981 \\
1976-1981 \\
1976-1981\end{array}$ \\
\hline $\begin{array}{l}\text { H Area } \\
\text { Outside } \\
\text { Facilities }\end{array}$ & $\begin{array}{l}\text { Uptake } \\
\text { Nasal } \\
\text { Skin } \\
\text { Clothing }\end{array}$ & $\begin{array}{l}1 \\
2 \\
2 \\
10\end{array}$ & $\begin{array}{l}- \\
- \\
-\end{array}$ & $\begin{array}{l}4380 \\
1095 \\
1095 \\
219\end{array}$ & $\begin{array}{l}- \\
- \\
-\end{array}$ & $\begin{array}{l}1970-1981 \\
1976-1981 \\
1976-1981 \\
1976-1981\end{array}$ \\
\hline $\begin{array}{l}\text { Tritium } \\
232-\mathrm{H}\end{array}$ & $\begin{array}{l}\text { Uptake/Inhal. } \\
\text { Uptake/Absorp. } \\
\text { Personnel }\end{array}$ & $\begin{array}{l}15 \\
10 \\
0\end{array}$ & $\begin{array}{l}\text { Weibull } \\
- \\
-\end{array}$ & $\begin{array}{l}319 \\
474 \\
-\end{array}$ & $\begin{array}{l}34 \\
312 \\
-\end{array}$ & $\begin{array}{l}1970-1982 \\
1970-1982 \\
1970-1982\end{array}$ \\
\hline $\begin{array}{l}\text { Tritium } \\
234-\mathrm{H} \\
236-\mathrm{H}\end{array}$ & $\begin{array}{l}\text { Uptake/Inhal. } \\
\text { Uptake/Absorp. } \\
\text { Personne1 }\end{array}$ & $\begin{array}{l}21 \\
24 \\
3\end{array}$ & $\begin{array}{l}\text { Exponential } \\
\text { Weibul1 } \\
\text { - }\end{array}$ & $\begin{array}{l}153 \\
190 \\
1581\end{array}$ & $\begin{array}{l}106 \\
72 \\
-\end{array}$ & $\begin{array}{l}1970-1982 \\
1970-1982 \\
1970-1982\end{array}$ \\
\hline $\begin{array}{l}\text { Tritium } \\
237-\mathrm{H} \\
238-\mathrm{H}\end{array}$ & $\begin{array}{l}\text { Uptake/Inhal. } \\
\text { Uptake/Absorp. } \\
\text { Personnel }\end{array}$ & $\begin{array}{l}1 \\
0 \\
0\end{array}$ & $\begin{array}{l}- \\
- \\
-\end{array}$ & $\begin{array}{l}4745 \\
- \\
-\end{array}$ & $\begin{array}{l}- \\
- \\
-\end{array}$ & $\begin{array}{r}1970-1982 \\
\cdot 1970-1982 \\
1970-1982\end{array}$ \\
\hline
\end{tabular}




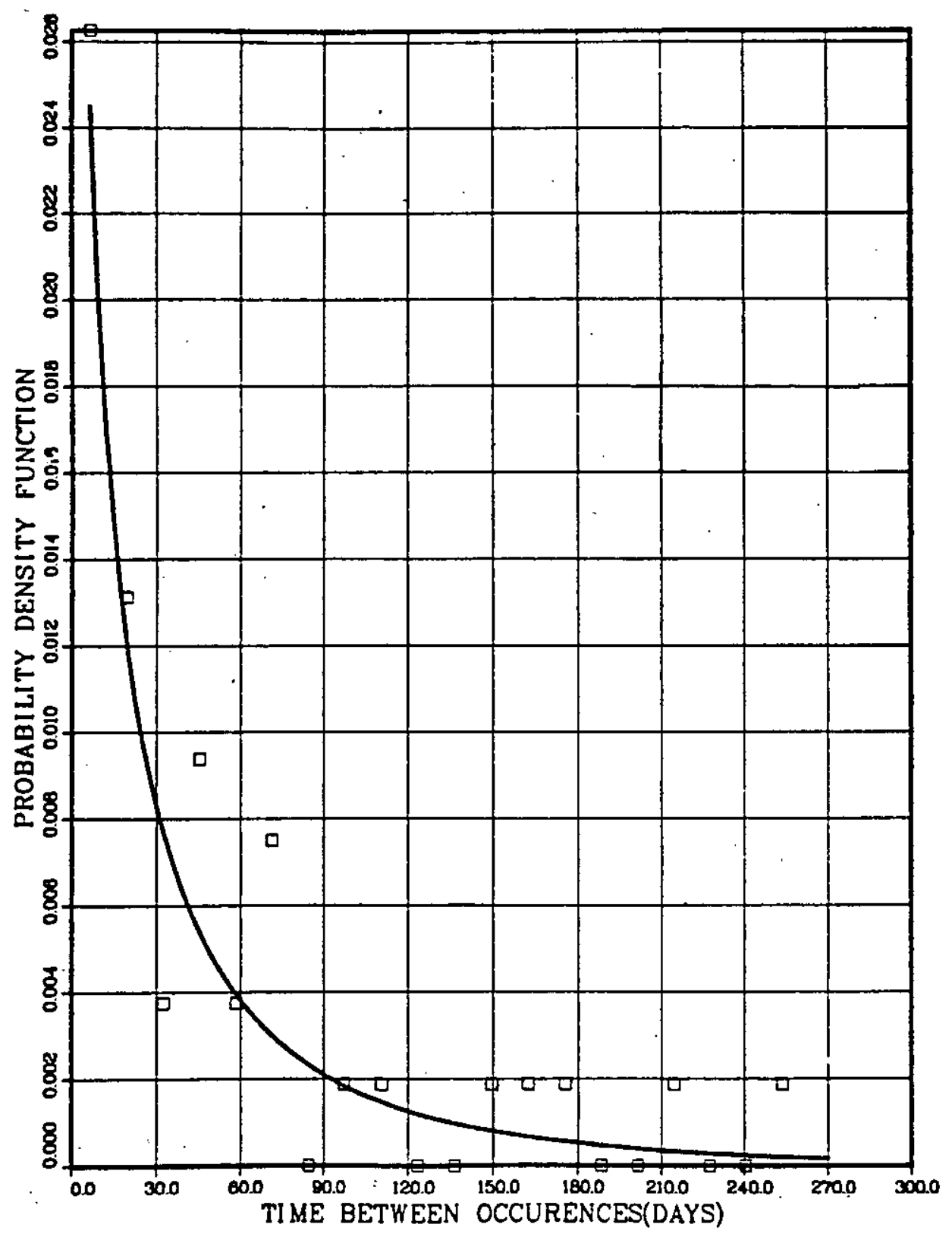

FIGURE 1. Probability Density Function for Skin Contaminations in F-Canyon 


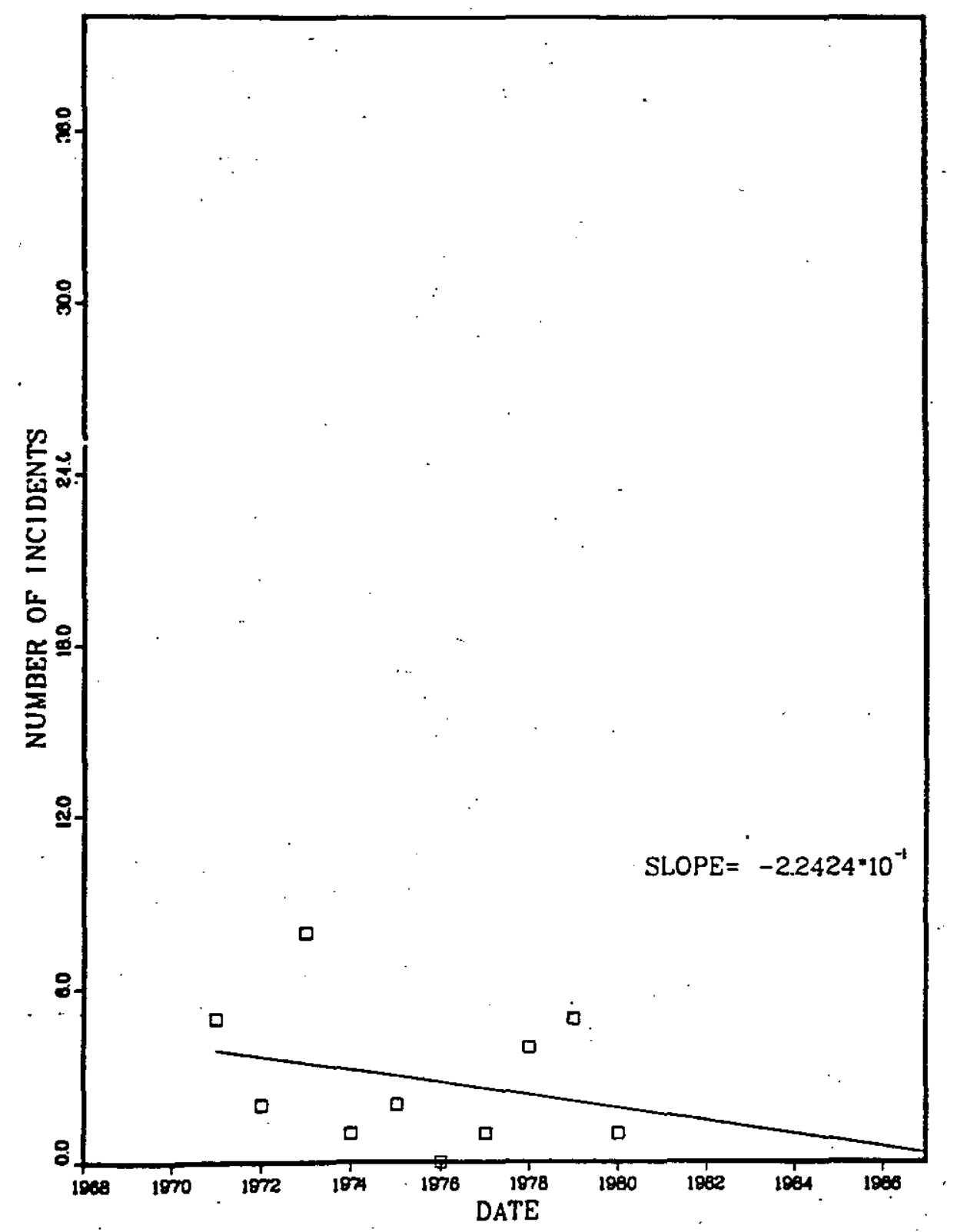

FIGURE 2. Trend Plot of Uptakes by Inhalation for JB-Line 
DPST $-83-508$

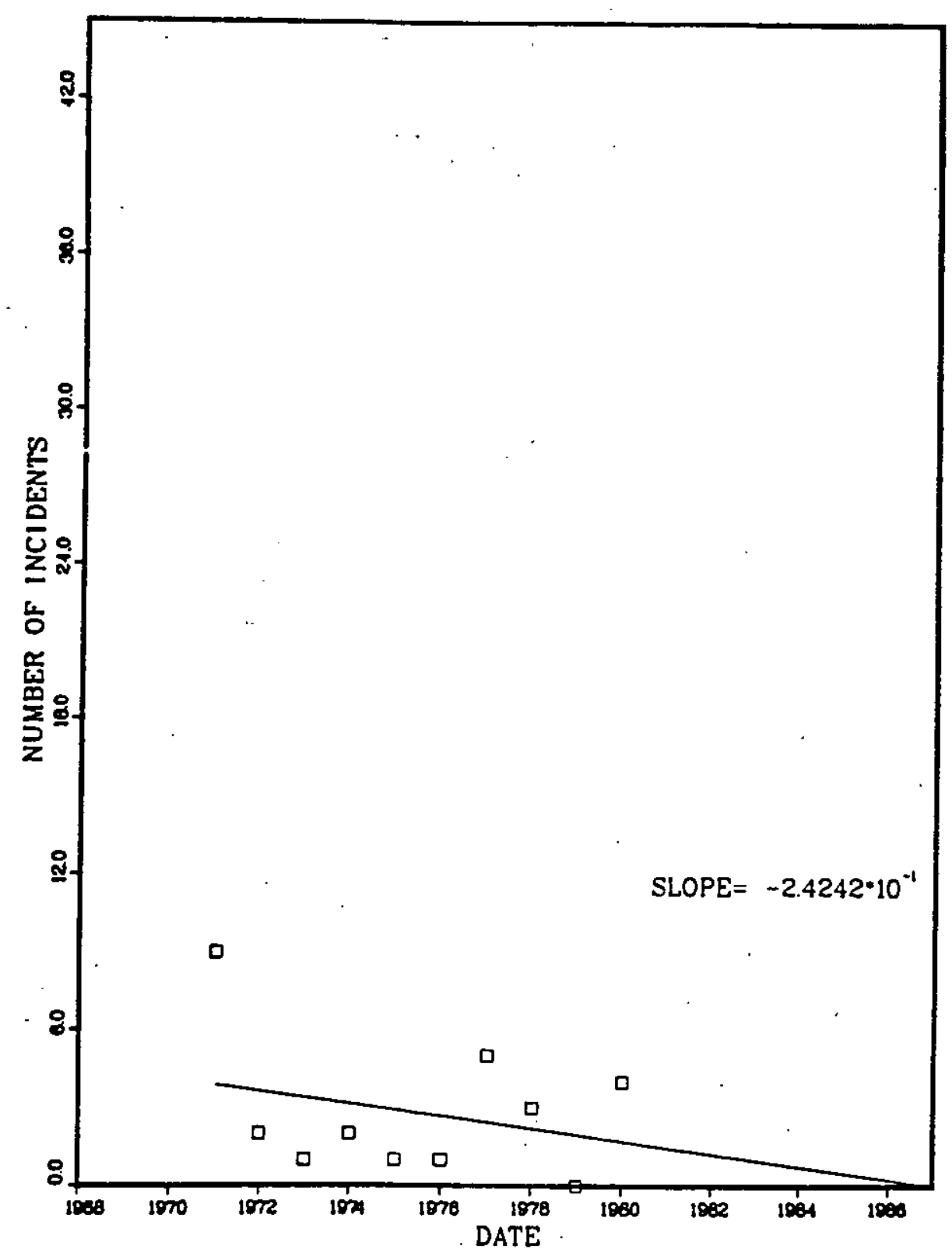

FIGURE 3. Trend Plot of Uptakes by Inhalation for 772-F 


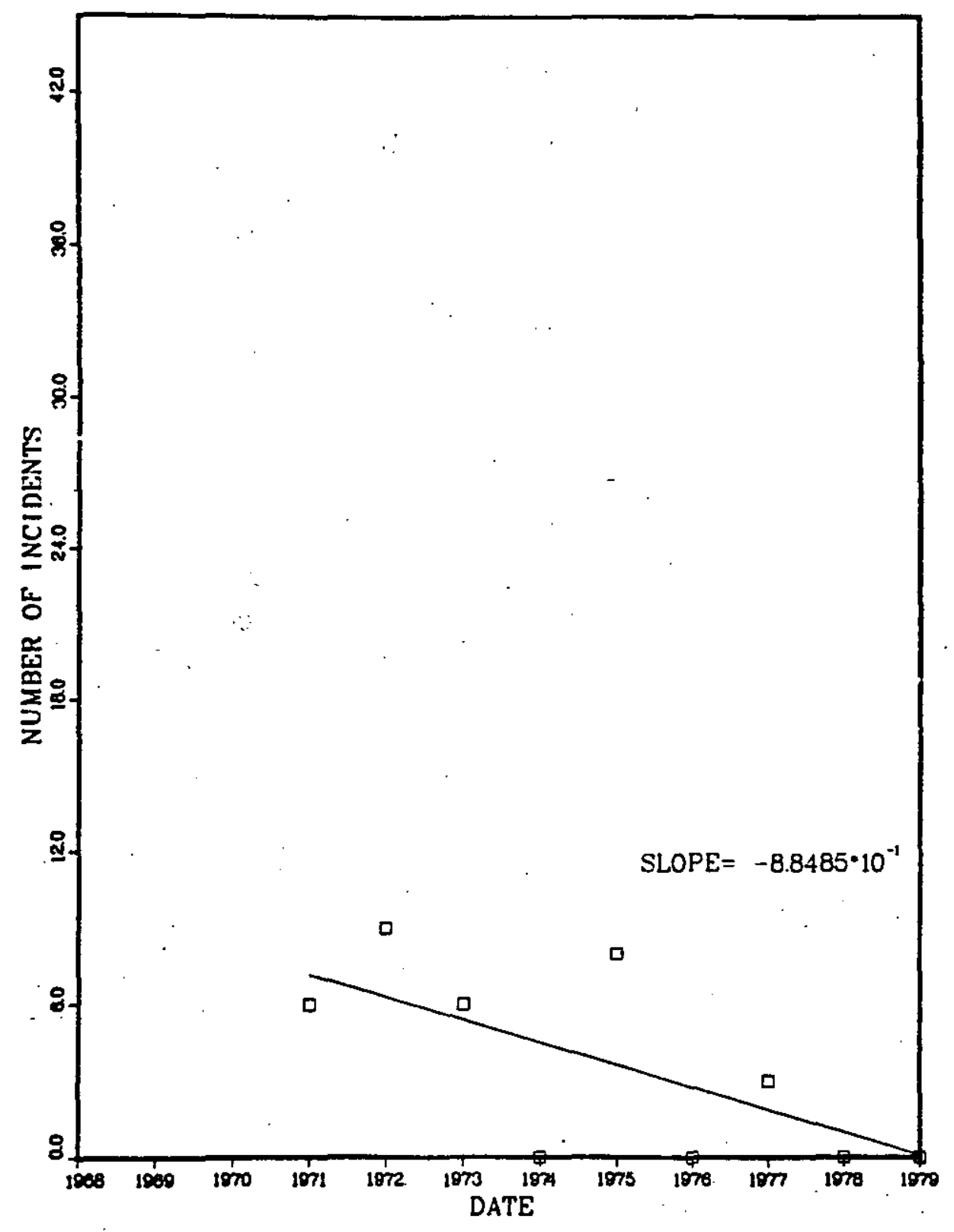

FIGURE 4. Trend Plot of Uptakes by Inhalation for H-Canyon 


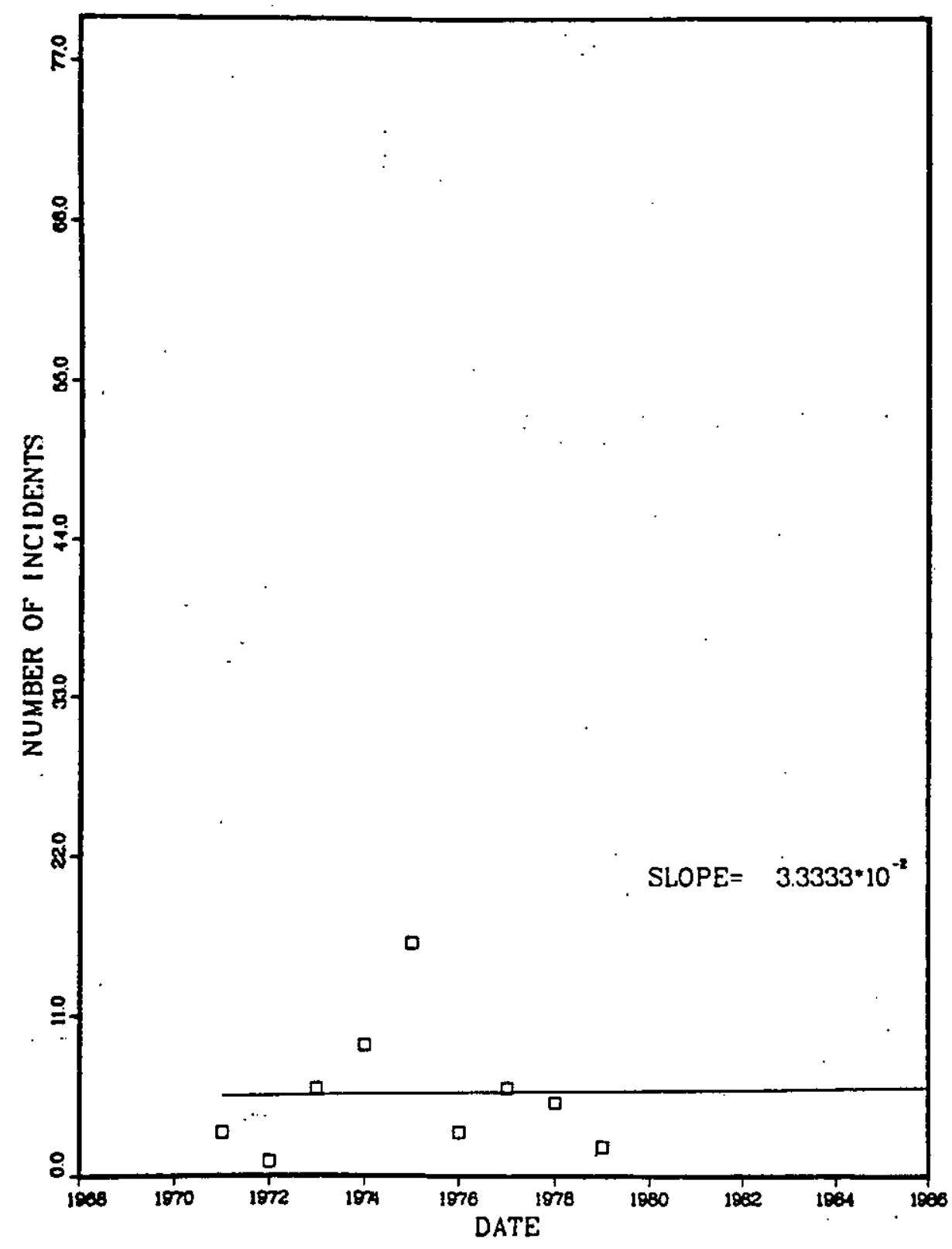

FIGURE 5. Trend Plot of Uptakes by Inhalation for HB-Line 


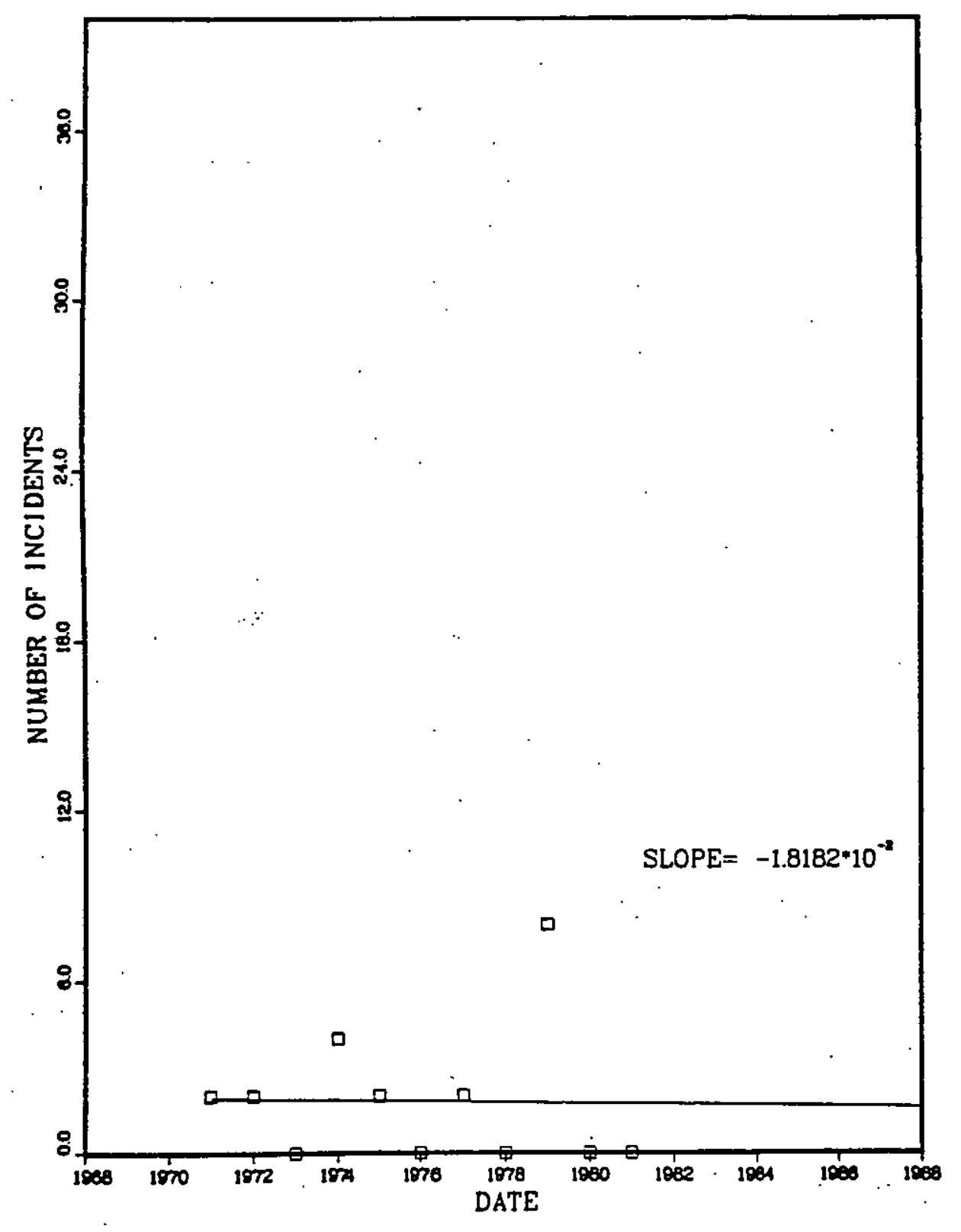

FIGURE 6. Trend Plot of Uptakes by Absorption for 234-B and 236-H (Tritium) 


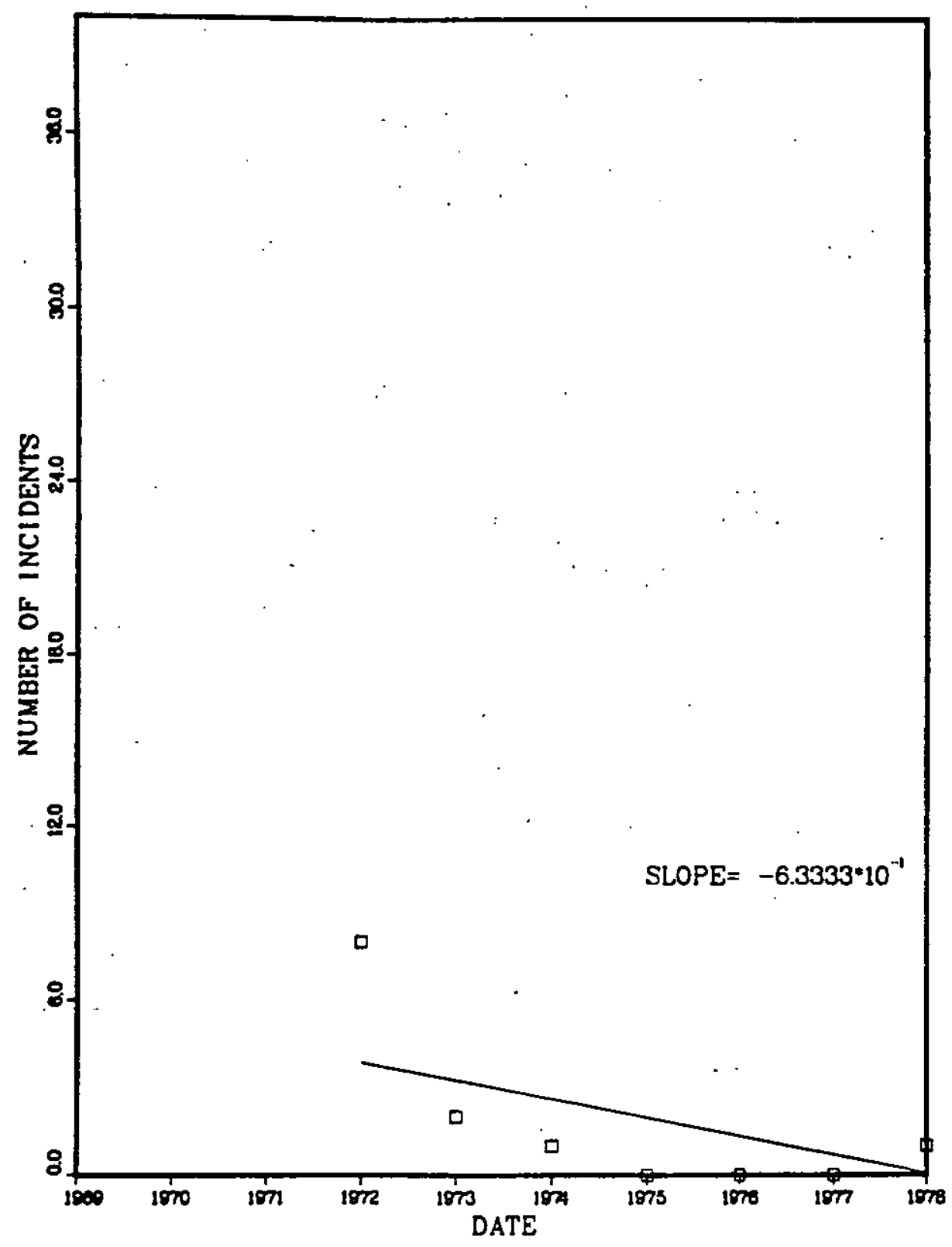

FIGURE 7. Trend Plot of Uptakes by Inhalation for 232-H (Tritium) 
$-; \ln$.

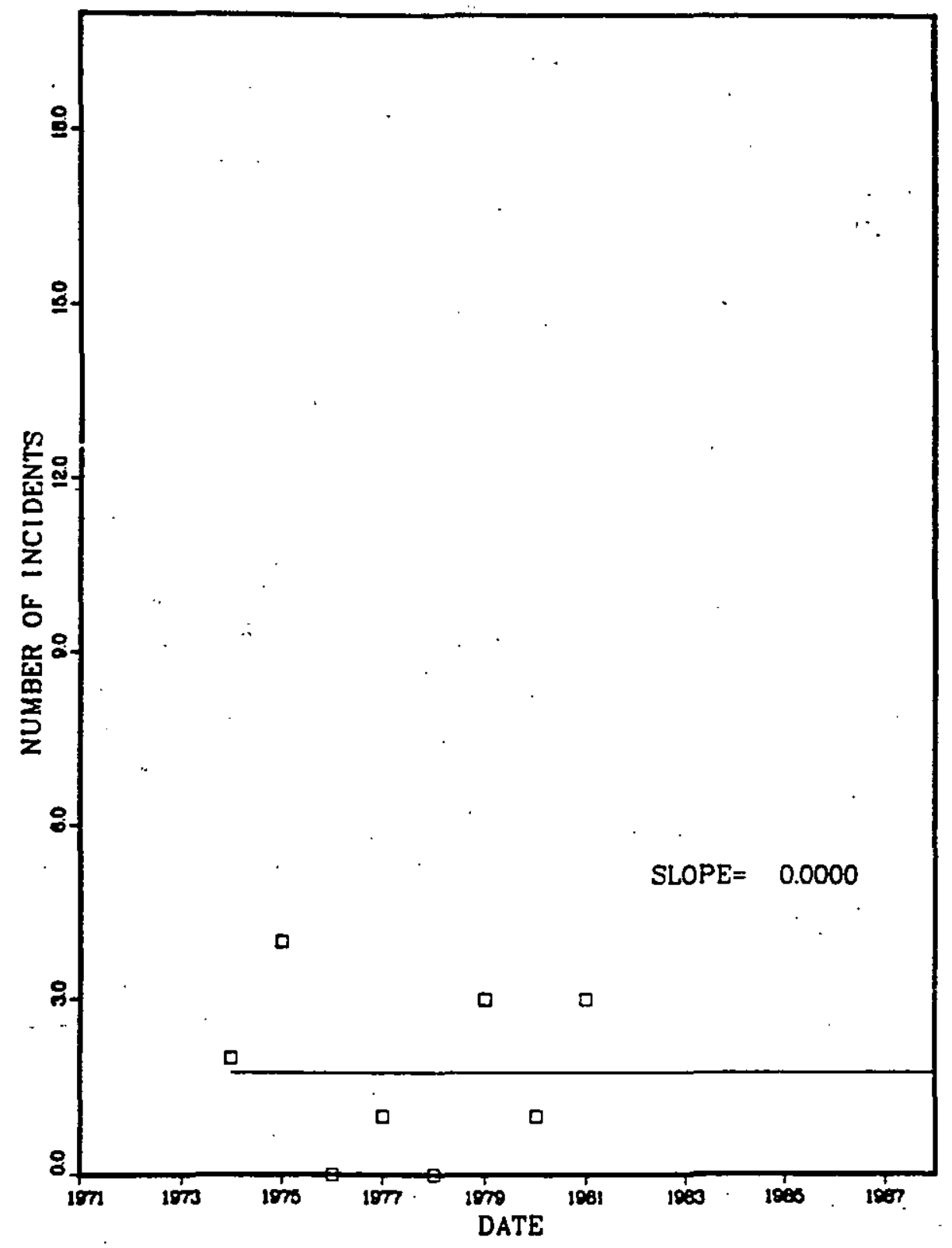

FIGURE 8. Trend Plot of Uptakes by Inhalation for 234-H and 236-H (Tritium) 


\title{
A STATISTICAL ANALYSIS OF PERSONNEL CONTAMINATIONS IN 200 AREA FACILITIES (U)
}

by

\author{
M. A. Wagner and D. H. Stoddard \\ E. I. du Pont de Nemours \& Company \\ Savannah River Site \\ Aiken, South Carolina 29808
}

This report was prepared in connection with work done under Contract No. DE-AC09-76SR0001 with the U.S. Department of Energy. By acceptance of this report, the publisher and/or recipient acknowledges the U.S. Government's right to retain a nonexclusive, royalty-free license in and to any copyright covering this report, along with the right to reproduce and to authorize others to reproduce all or part of the copyrighted report. 
Letter (DPST-83-508TL) H. D. Harmon to J. T. Granaghan dated $6 / 17 / 83$

Distribution:

A. H. Peters, SRP, 703-A

T. Hendrick, 703-A

D. L. McIntosh, 703-A

J. D. Spencer, 703-A

E. O. Kiger, 703-A

L. M. Papouchado, 703-A

W. C. Reinig, 703-A

J. P. Duane, 221-F

C. H. Cofer, 704-F

R. M. Hall, 735-A

K. Q. Gambill, 735-A

S. Mirshak, SRL, 773-A

S. D. Harris, 773-A

W. S. Durant, 773-26A

R. M. Mobley, 773-A

M. B. Hughes, 773-A

W. V. Wright, 773-19A

W. C. Perkins, 773-26A

J. C. Huang, 773-26A

T. F. Schlaf, 773-26A

$\mathrm{H}$. R. Haynes, 773-26A

R. Lee, 773-26A

P. M. Allen, 773-26A

D. H. Stoddard, 773-26A

M. A. Wagner, 676-G

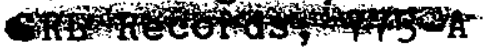

